\title{
Correlation of Maturity Parameters Derived from Methylphenanthrenes and Methyldibenzothiophenes in the Carboniferous Source Rocks from Qaidam Basin, NW China
}

\author{
Chuan He, ${ }^{1,2}$ Haiping Huang $\mathbb{D}^{1,2}$ Qianru Wang, ${ }^{2}$ and Zongxing $\mathrm{Li}^{3}$ \\ ${ }^{1}$ School of Energy Resource, China University of Geosciences, Beijing 100083, China \\ ${ }^{2} P R G$, Department of Geoscience, University of Calgary, T2N1N4, Calgary, AB, Canada \\ ${ }^{3}$ The Key Laboratory of Shale Oil and Gas Geological Survey, Institute of Geomechanics, Chinese Academy of Geological Sciences, \\ Beijing 100081, China
}

Correspondence should be addressed to Haiping Huang; huah@ucalgary.ca

Received 16 August 2019; Revised 27 September 2019; Accepted 11 October 2019; Published 21 December 2019

Academic Editor: Paola Cianfarra

Copyright (c) 2019 Chuan He et al. This is an open access article distributed under the Creative Commons Attribution License, which permits unrestricted use, distribution, and reproduction in any medium, provided the original work is properly cited.

Twenty-one core samples from the Carboniferous Keluke Formation in the Qaidam basin, NW China, have been geochemically characterized to investigate thermal maturation influence on the evolution behaviors of aromatic hydrocarbons and the validity of commonly used maturity parameters. The Keluke Formation was deposited in marine to continental transitional facies and dominated by type III kerogen. Rock-Eval $T_{\max }$ and vitrinite reflectance $\left(\% R_{\mathrm{o}}\right)$ measurement suggested that the studied samples are highly matured at peak oil to gas condensate generation stages. Most biomarkers lost their sensitivity to indicate maturity level due to either approaching the equilibrium point or too low concentrations, while isomer distributions in alkylnaphthalenes, alkylphenanthrenes, and alkyldibenzothiophenes still show systematic variations with increasing maturity. The present study focused on the maturity parameters derived from methylphenanthrenes (MP) and methyldibenzothiophenes (MDBT). The most widely used methylphenanthrene index 1 (MPI-1 $=1.5 \times(2-\mathrm{MP}+3-\mathrm{MP}) /(\mathrm{P}+9-\mathrm{MP}+1-\mathrm{MP}))$ shows no correlation with known maturity indicators, but the methylphenanthrene ratio $(\mathrm{MPR}=2-\mathrm{MP} / 1-\mathrm{MP})$ and methyldibenzothiophenes ratio $(\mathrm{MDR}=4-\mathrm{MDBT} / 1-\mathrm{MDBT})$ increase steadily with increasing maturity levels and are proved to be valid maturity parameters. However, empirical vitrinite reflectance estimations derived from MPR and MDR have dramatically overestimated the maturity levels. Our quantitative data illustrated that concentrations of thermally stable isomers (3-MP, 2-MP, and 4-MDBT) increase continuously with increasing maturity while thermally unstable isomers (9-MP, 1-MP, and 1-MDBT) are almost invariable in the studied maturity range. The invalidity of MPI-1 is caused by the involvement of phenanthrene in the maturity parameter formula possibly due to a variable degree of alkylation. Dealkylation of methylphenanthrenes to form parent phenanthrene occurs much earlier than $R_{\mathrm{o}}$ of $1.35 \%$ reported in the literature. The increment of MPR and MDR values with maturity levels is mainly caused by different generation rates with a higher generation rate of thermally stable isomer than thermally unstable counterpart rather than isomerization between them. Caution should be taken when empirical formula published in literature based on commonly used maturity parameters is directly applied for maturity estimation as no universal applicable correlation is likely available.

\section{Introduction}

Biomarkers are widely used for the assessment of thermal maturity, organic source inputs, and secondary alteration processes in source rocks, oils, and coals [1-5]. Thermal maturity of source rocks and oils is one of the most important parameters in petroleum exploration and appraisal, which is heavily relied on biomarkers. However, most parameters derived from steranes and hopanes are only valid at the low thermal maturity stage [6], because isomers have reached the equilibrium point at the early oil generation stage [7]. Meanwhile, their concentrations 
diminished significantly with increasing levels of maturity $[8,9]$.

The aromatic hydrocarbons derived from diagenesis and catagenesis processes of various biomarker precursors are abundant in source rock extracts and oils and are more stable than biomarkers at high maturity stage [10]. The relative abundance of methylated isomers, degree of alkylation, and numbers of aromatic rings in various aromatic and sulfurbearing aromatic hydrocarbons have been widely used to indicate thermal maturity especially for samples at the high maturity stage or samples without vitrinite reflectance measurement. There are numerous maturity parameters derived from alkylnaphthalenes, alkylphenanthrenes, and alkyldibenzothiophenes in the literature [11-19]. The methylphenanthrene index 1 (MPI-1 $=1.5 \times(2-\mathrm{MP}+3-\mathrm{MP}) /(\mathrm{P}+$ $1-\mathrm{MP}+9-\mathrm{MP})$ ) proposed by Radke et al. [16] was probably one of the most widely used ones. Linear correlation between MPI-1 and vitrinite reflectance has been observed at different maturity levels. The empirical estimation of vitrinite reflectance $\left(\% R_{\mathrm{o}}\right)$ can be expressed as $R_{\mathrm{c}}=0.6 \times \mathrm{MPI}-1+0.4$ for the $R_{\mathrm{o}}<1.35 \%$ and $R_{\mathrm{c}}=-0.6 \times \mathrm{MPI}-1+2.3$ for the $R o>$ $1.35 \%[14,16,20]$. The $R_{\mathrm{o}}$ value of $1.35 \%$ was regarded as a critical point shifted from methylation and rearrangement to demethylation [20]. Similar parameters including MPI-2 $(=3 \times(2-\mathrm{MP}) /(\mathrm{P}+1-\mathrm{MP}+9-\mathrm{MP}),[16]), \mathrm{MPI}-3(=(3-\mathrm{MP}+$ $2-\mathrm{MP}) /(9-\mathrm{MP}+1-\mathrm{MP}), \quad[17])$, and MPR (=2-MP/1-MP, [20]) are also commonly used in oil and source rock maturity estimations. The principle to apply methylphenanthrene isomer distribution as a maturity indicator is based on the thermal stability of isomers at different substituent positions. The $\beta$-substituent isomers are thermally more stable than the $\alpha$ substituent counterparts. The 3- and 2-MP have a bridgehead position ( $\beta$-type) and are believed to be more stable than 9and 1-MP ( $\alpha$-type), which can be derived from the rearrangement 1- and 9-MP and/or from phenanthrene through methylation [16]. Aromatic sulfur compounds have also been demonstrated to be very important in evaluating the maturity of crude oils and source rocks [4, 17, 21]. For methyldibenzothiophene (MDBT) isomers, 4-MDBT bears the $\beta$-substituent, while 1-MDBT has an $\alpha$-substituent and the methyldibenzothiophene ratio $(\mathrm{MDR}=4-\mathrm{MDBT} / 1-\mathrm{MDBT}$, [17]) was proposed based on the same principle as methylphenanthrene index.

While parameters derived from the aromatic and sulfurbearing aromatic hydrocarbons were regarded as versatile tools in maturity studies especially for oil maturity level estimation or source rocks due to either difficulty in vitrinite reflectance measurement or absence of vitrinites [22-27], their limitations and restrictions caused by organofacies interference have been well recorded $[1,17,28,29]$. The MPI-1 seemed only work for types III and III/II kerogens and encountered problems for type I kerogen [17]. Püttmann et al. [29] indicated the invalid MPI-1 maturity estimation was caused by unusually high alginite concentration and low abundance of aromatic compounds, while Cassini et al. [28] attributed anomalous MPI-1 values to lithologic variations. However, while variable kerogen types were accounted, the MPI- 1 and measured $R_{\mathrm{o}}$ value correlation still diverged in different case histories. Boreham et al. [30] suggested an alternative calibration of MPI- 1 to vitrinite reflectance for type III kerogens as follows: $R_{\mathrm{c}}=0.7 \times \mathrm{MPI}-1+0.22$ for $R_{\mathrm{o}}<1.7 \%$ and $R_{\mathrm{c}}=-0.55 \times \mathrm{MPI}-1+3.0$ for $R_{\mathrm{o}}>1.7 \%$. Chandra et al. [31] found the regression equation of MPI-1 vs. $\% R_{\mathrm{o}}$ differed from both Radke et al. [16] and Boreham et al. [30] and their linear regression for type III kerogen was expressed as $R_{\mathrm{c}}=0.291 \times \mathrm{MPI}-1+0.293$. The calibration performed by Norgate et al. [32] for the Buller coals results in the following equation: $R_{\mathrm{c}}=1.1 \times \mathrm{MPI}-1+0.07$. More empirical correlation between MPI- 1 and measured vitrinite reflectance value may exist in literature. Nevertheless, Radke et al. [17] concluded that organofacies compromised MPI-1 parameter mainly occurred at the low maturity stage but would be particularly useful in the maturity evaluation of postmature crude oils and condensates.

While the invalidity of commonly used maturity parameters can be partially attributed to the variable nature of organic input, the reaction mechanisms govern these parameters were also poorly understood. Isomerization between thermally stable isomers and unstable isomers was commonly assumed; however, quantitative data in both biomarkers and aromatic hydrocarbons can hardly support such assumptions $[7,18,33]$. Alkylation and dealkylation of aromatic hydrocarbons are very complicated processes, and whether the assumption from alkylation to dealkylation in alkylphenanthrenes at $R_{\mathrm{o}}$ of $1.35 \%$ [16] is valid in all sedimentary basins or not has not been thoroughly investigated. In the present study, quantitative data have been generated from the highly matured Carboniferous samples dominated by type III kerogens in the Qaidam basin, NW China. The purpose of our study is to investigate the thermal evolution behavior of methylphenanthrene and methyldibenzothiophene isomers and further our understanding of the validity of most commonly used parameters in maturity assessment.

\section{Geologic Settings}

Qaidam basin is located in the northern part of the QinghaiTibet plateau encompassing an area of $12,100 \mathrm{~km}^{2}, 850 \mathrm{~km}$ long and $150-300 \mathrm{~km}$ wide (Figure 1, [34]). It is an active intermountain basin surrounded by Qilian Mountains, Kunlun Mountains, and Altyn Mountains [35]. Qaidam basin is a prolific oil and gas production province, which is formed with complex evolutionary history and its basic petroleum geological characters have been investigated by numerous studies [34, 36-38].

Qaidam basin can be divided into eastern and western parts. The western side of the basin has experienced strong structural denaturation and metamorphism, while tectonic activity on the eastern side is relatively weak. The eastern part of the Qaidam basin is surrounded by Zongnan Fault, Oubei Fault, and Aibei Fault and consists of Delingha depression, Oulongbuluke bungle, Ounan depression, Aimunike bungle, and Nuomuhong depression. The Carboniferous strata are widely developed in the basin, which can be divided into the Chuanshangou, Chengqianggou, Huaitoutala, Keluke, and Zabusagaxiu formations (from oldest to youngest). Samples in the present study are from the Keluke Formation, which is the potential source rock layer of the Qaidam basin. 


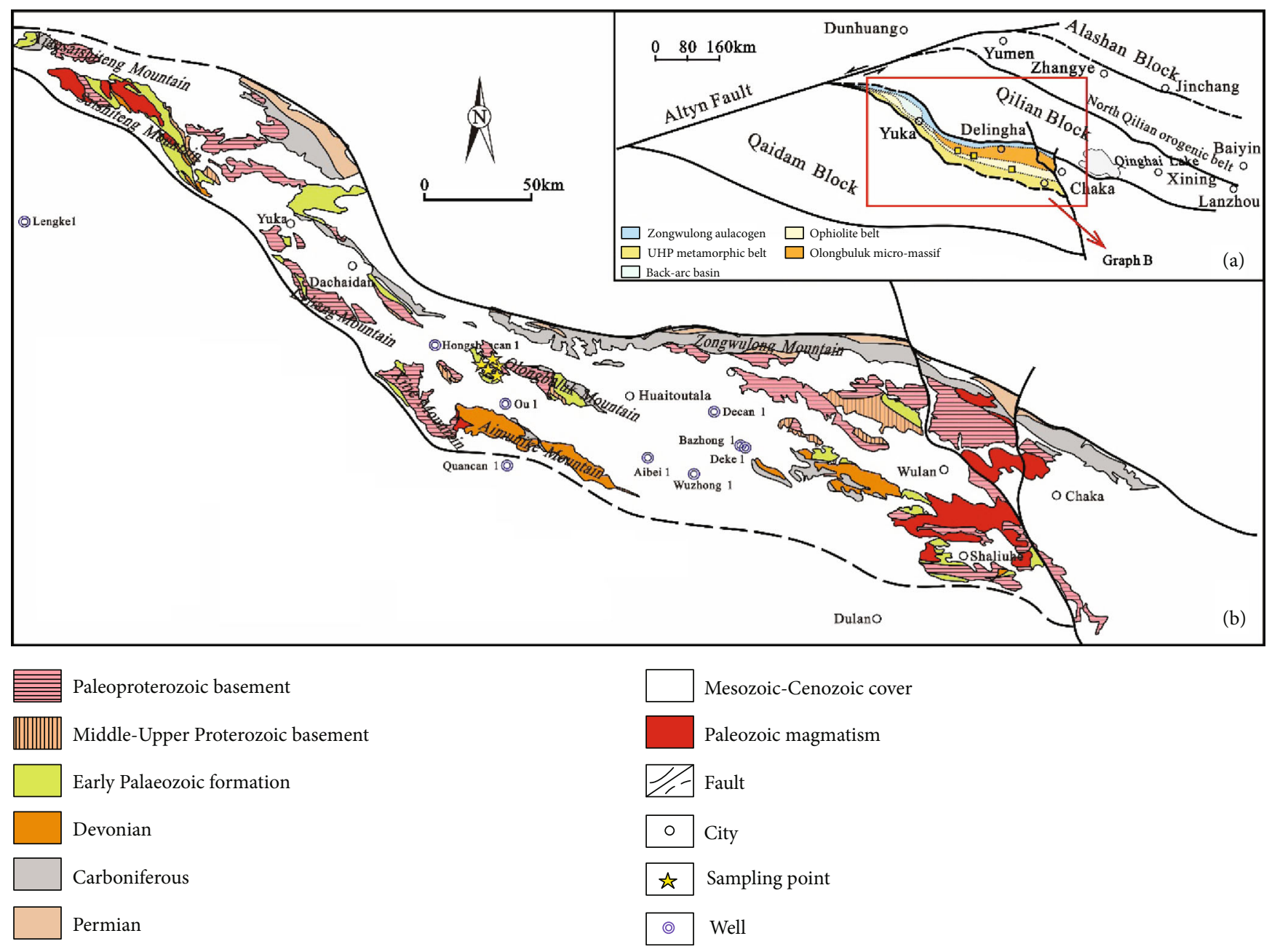

FIGURE 1: Schematic map of the eastern Qaidam basin and sample locations (modified from Li et al., 2016).

The Keluke Formation was developed from platformal facies carbonate to marine-terrigenous transitional facies with a thickness of 400-700 m. The lower part of the formation consists mainly of dark mudstone and shale with sporadic coal interbedded, while the upper part of the formation comprises mainly sandstone, shale, and limestone. Four lithologic facies can be recognized within the Keluke Formation [36]. The Carboniferous strata in the Qaidam basin is still in the early exploration stage, and no commercial oil and gas have been discovered so far. However, oil and gas shows have been encountered in some wells, and oil seeps are common in surrounding outcrops. Oil-source correlation based on biomarkers suggested that these oil shows and seeps were derived from the Keluke Formation [37-39]. Minor amount of oil and gas was successfully tested in recently drilled well CY2 from the Keluke Formation, further proof the hydrocarbon generation potential.

\section{Samples and Experimental Methods}

Twenty-one core samples were collected from 5 wells (ZK11, ZK2-1, ZK2-2, ZK5-1, and ZK5-2) in the Upper Carboniferous Keluke Formation at eastern Qaidam basin. The research area is a depression in Qinghai-Tibet plateau [40, 41], and no significant differential elevation exists between the studied wells. Basic geochemical features were obtained from Rock-Eval 6 apparatus by using the standard pyrolysis heating program [42]. The random vitrinite reflectance was measured on whole rock with an Axioplan-Opton microphotometer and Opton 20 Microscope System Processor at $546 \mathrm{~nm}$ in oil. The reported value was an arithmetic mean of at least 25 measurement points per sample. Extractable organic matter (EOM) was obtained from Soxhlet extraction by using a mixture of dichloromethane and methanol (93:7, $v: v)$ for 72 hours. Activated copper was used to remove sulfur from the extracts. About $50 \mathrm{mg}$ EOM spiked with a suite of internal standards $\left(\mathrm{d}_{8}\right.$-naphthalene, $\mathrm{d}_{10}$-phenanthrene, 1,1-binaphthyl, squalane, and d16-adamantane and $\mathrm{d}_{4}$-cholestane) was loaded onto a polar florisil solid phase extraction (SPE) cartridge to remove asphaltenes. The deasphaltened maltene fraction was then separated into hydrocarbon (HC) and polar fractions using hexane and dichloromethane as eluents in a nonendcapped C18 SPE cartridge. The hydrocarbon fraction was further separated into the aromatic and saturated $\mathrm{HC}$ fractions using a modified Bastow method [43]. 
Gas chromatography-mass spectrometry (GC-MS) was performed with an Agilent 5975C MSD system interfaced to an Agilent $7890 \mathrm{~A}$ gas chromatograph. Saturated hydrocarbon was injected into a $60 \mathrm{~m} \mathrm{DB}-1 \mathrm{MS}$ fused silica capillary column $\left(0.32 \mathrm{mmi}\right.$ i.d. $\times 0.25 \mu \mathrm{m}$ film thickness) at $20^{\circ} \mathrm{C}$, and the aromatic hydrocarbon was injected into a $60 \mathrm{~m}$ HP-5MS column $(0.32 \mathrm{~m} \times 0.25 \mu \mathrm{m})$. Helium was used as the carrier gas with a constant flow rate of $1 \mathrm{ml} / \mathrm{min}$, and the temperature program was started at $40^{\circ} \mathrm{C}$ for 5 minutes, then raised to $325^{\circ} \mathrm{C}$ at the rate of $3^{\circ} \mathrm{C} / \mathrm{min}$, followed by an isothermal phase of $20 \mathrm{~min}$. The MSD operated at an ion source temperature of $300^{\circ} \mathrm{C}$ and the electron ionization mode at $70 \mathrm{eV}$ with selected ion monitoring used. Peak area against the internal standard $\left(\mathrm{d}_{10}\right.$-phenanthrene) was used for the concentration calculation of phenanthrene, methylphenanthrenes, and methyldibenzothiophenes. Two standard oil samples, one blank sample, and one duplicate sample have been added to calibrate the concentration, but no response factor calibration has been performed in this study.

\section{Results}

4.1. Bulk Compositions. Results from Rock-Eval pyrolysis of the samples are presented in Table 1. The total organic carbon (TOC) values vary from 0.30 to $6.83 \mathrm{wt} \%$ with an average of $2.36 \%$, indicating organic-rich source rocks. However, most organic matter determined by TOC is residual carbon (RC), which was calculated by the generated carbon dioxide after oxidation at $800^{\circ} \mathrm{C}$ and suggested depleted hydrocarbon generation potential. The free hydrocarbon contents released before $300^{\circ} \mathrm{C}\left(S_{1}\right)$ are in the range of 0.02 to $0.61 \mathrm{mg} / \mathrm{g}$ rock with an average value of $0.12 \mathrm{mg} / \mathrm{g}$ rock. The pyrolyzed hydrocarbon contents generated during $300-600^{\circ} \mathrm{C}$ heating process $\left(S_{2}\right)$ vary from 0.15 to $5.11 \mathrm{mg} / \mathrm{g}$ rock and are averaged at $1.35 \mathrm{mg} / \mathrm{g}$ rock. The hydrogen index $\left(\mathrm{HI}=\mathrm{S}_{2} / \mathrm{TOC}\right)$ values are in the range of $25-84 \mathrm{mg} \mathrm{HC} / \mathrm{g}$ TOC, indicating exhausted source rock nature. Low production index $\left(\mathrm{PI}=S_{1} /\left(S_{1}+S_{2}\right)\right)$ values of 3.9-18.5\% likely reflect the loss of generated hydrocarbons during the elevation of strata in geohistory, which is also evidenced by low EOM yields of $0.07-0.82 \mathrm{mg} / \mathrm{g}$.

Rock-Eval $T_{\max }$, the temperature at maximum $S_{2}$ yield, ranges from 455 to $481^{\circ} \mathrm{C}$, indicating a highly mature stage in terms of oil and gas generation. Vitrinite reflectance values of 12 measured samples vary from 0.74 to $1.37 \%$, which were correlated to $T_{\max }$ values with the equation of $R_{\mathrm{o}}=0.024 \times T_{\max }-9.90$ with a correlation coefficient of 0.93 (Figure 2(a)). The calculated values from $R_{\mathrm{o}}=0.0180$ $\times T_{\max }-7.16$ [44] are about $0.2 \%$ higher than the measured ones; therefore, 9 samples without vitrinite reflectance measurement were calculated based on our own correlation.

Cross plot of $\mathrm{HI}$ and $T_{\max }$ illustrated that most of our studied samples are type III kerogen (Figure 2(b)), which is consistent with petrography analysis in adjacent samples by other studies $[45,46]$.

4.2. Molecular Compositions. Total ion chromatograms (TICs) of saturated hydrocarbon fraction are dominated by $n$-alkanes with a minor amount of branched and isoprenoid alkanes but almost absent of biomarkers (data not shown). TICs of aromatic hydrocarbon fraction are dominated by alkylnaphthalenes and alkylphenanthrenes with minor amount of alkyldibenzothiophenes and tetra-aromatic compounds but absence of mono- and triaromatic steroids (Figure 3). The distributions of aromatic hydrocarbons vary with maturity levels. In relatively low maturity samples represented by a sample at $114 \mathrm{~m}$ in well ZK5-1, relative abundances of bicyclic aromatic hydrocarbon compound including C0-5 alkylnaphthalenes and C0-2 alkylbiphenyls account for $66.3 \%$ in total quantified aromatic compounds, tricyclic compound including C0-3 alkylphenanthrenes and C0-1 alkylfluorenes occupied $18.3 \%$, tetracyclic aromatic hydrocarbons including pyrene, fluoranthene, chrysene, and their methylated homologs for $12.6 \%$, and pentacyclic aromatic compound including benzofluoranthenes and benzopyrenes for $2.8 \%$. As the vitrinite reflectance raise to $0.98 \%$ and $1.22 \%$, the relative abundance of bicyclic aromatic hydrocarbon compound decreases to $63.8 \%$ and $54.9 \%$, respectively, while the percentage of tricyclic compounds grows up to $25.3 \%$ and $29.4 \%$, respectively. The tetracyclic aromatic compounds do not change too much at $9.1 \%$ and $13.3 \%$, and the pentacyclic aromatic compounds are $1.8 \%$ and $2.4 \%$, respectively.

Partial selected ion mass chromatograms of $m / z$ (192 and 198) show the distribution of methylphenanthrene and methyldibenzothiophene isomers in Figure 4. At $R_{\mathrm{o}}$ of $0.79 \%$, the 9 -MP has similar abundance as $2-\mathrm{MP}$. The relative abundance of 3- and 2-MP was increased with maturity while that of 9- and 1-MP decreased accordingly (Figure 4(a)). Concentrations of 3- and 2-MP raise from $83 \mu \mathrm{g} / \mathrm{g}$ EOM (ppm) and $131 \mathrm{ppm}$ to 2481 and $3337 \mathrm{ppm}$ when $\% R_{\mathrm{o}}$ values increase from 0.74 to $1.37 \%$, while those of 9 - and 1-MP are from 133 and $69 \mathrm{ppm}$ to 1407 and $1012 \mathrm{ppm}$, respectively. Meanwhile, the concentration of phenanthrene increases from 736 to $5608 \mathrm{ppm}$ in the same maturity interval (Figure 5). The MPI-1 in the studied samples varies from 0.34 to 1.34 and shows no linear relationship with burial depth (Figure 6(a)); however, MPI-3 is well correlated to vitrinite reflectance with the equation of $R_{\mathrm{o}}=0.21 \times \mathrm{MPI}-3+$ 0.65 and correlation coefficient of 0.58 (Figure 7). The methylphenanthrene ratio (MPR) also increases from 1.6 to 5.8 with increasing $R_{\mathrm{o}}$ values.

Mass chromatograms of $\mathrm{m} / \mathrm{z} 198$ (Figure 4(b)) shows the increment of 4-MDBT against 1-MDBT with increasing maturity levels. The concentration of 4-MDBT increases from 18 to $628 \mathrm{ppm}$ when $\% R_{\mathrm{o}}$ values raise from 0.74 to $1.37 \%$, while the change of $1-\mathrm{MDBT}$ is from 4 to $24 \mathrm{ppm}$ (Figure 8). The MDR value increases from 5 to 48 accordingly with increasing $R_{\mathrm{o}}$ values. A linear relationship between MDR and burial depth can be established as depth $=14 \times \mathrm{MDR}-35$ with a correlation coefficient of 0.66 (Figure 6(b)).

\section{Discussion}

5.1. Mechanisms Govern the Variations of Methylphenanthrene and Methyldibenzothiophene Isomer Distributions. MPI-1 
TABLE 1: Basic sample information and results from Rock-Eval pyrolysis, vitrinite reflectance measurement, and solvent extraction.

\begin{tabular}{|c|c|c|c|c|c|c|c|c|c|c|c|c|c|}
\hline Well & Depth (m) & Lithology & $\begin{array}{c}S_{1} \\
\mathrm{mg} / \mathrm{g}\end{array}$ & $\begin{array}{c}\mathrm{S}_{2} \\
\mathrm{mg} / \mathrm{g}\end{array}$ & ${ }^{T_{\max }} \mathrm{C}$ & $\begin{array}{l}\text { PI } \\
\%\end{array}$ & $\begin{array}{c}\mathrm{HI} \\
\mathrm{mg} / \mathrm{g} . \mathrm{c}\end{array}$ & $\begin{array}{c}\mathrm{RC} \\
\%\end{array}$ & $\begin{array}{c}\text { TOC } \\
\%\end{array}$ & $\begin{array}{l}R_{\mathrm{o}} \\
\%\end{array}$ & $\delta \mathrm{n}$ & $\begin{array}{c}R_{\mathrm{c}-t \max } \\
\%\end{array}$ & $\begin{array}{l}\mathrm{EOM} \\
\mathrm{mg} / \mathrm{g}\end{array}$ \\
\hline ZK1-1 & 88.6 & Mudstone & 0.06 & 0.36 & 470 & 14.29 & 35 & 0.98 & 1.03 & 1.09 & 0.07 & & 0.23 \\
\hline ZK1-1 & 110.1 & S. mudstone & 0.29 & 2.97 & 466 & 8.90 & 71 & 3.88 & 4.17 & & & 1.00 & 0.58 \\
\hline ZK1-1 & 127.1 & Mudstone & 0.15 & 1.18 & 473 & 11.28 & 61 & 1.78 & 1.92 & 1.11 & 0.05 & & 0.39 \\
\hline ZK1-1 & 196.2 & S. mudstone & 0.04 & 0.29 & 459 & 12.12 & 33 & 0.84 & 0.88 & & & 0.84 & 0.50 \\
\hline ZK1-1 & 220.5 & Mudstone & 0.16 & 1.87 & 473 & 7.88 & 68 & 2.58 & 2.77 & 1.14 & 0.11 & & 0.58 \\
\hline ZK1-1 & 310.2 & S. mudstone & 0.13 & 1.15 & 481 & 10.16 & 42 & 2.61 & 2.73 & & & 1.36 & 0.32 \\
\hline ZK1-1 & 324 & Mudstone & 0.10 & 1.21 & 476 & 7.63 & 37 & 3.11 & 3.24 & 1.22 & 0.09 & & 0.55 \\
\hline ZK5-1 & 114 & Mudstone & 0.11 & 0.66 & 455 & 14.29 & 50 & 1.25 & 1.33 & 0.79 & 0.10 & & 0.23 \\
\hline ZK5-1 & 210 & Siltstone & 0.13 & 2.09 & 462 & 5.86 & 84 & 2.29 & 2.50 & 0.98 & 0.14 & & 0.48 \\
\hline ZK5-1 & 253 & S. mudstone & 0.61 & 5.11 & 457 & 10.66 & 75 & 6.33 & 6.83 & & & 0.79 & 0.82 \\
\hline ZK5-1 & 350 & Siltstone & 0.03 & 0.39 & 478 & 7.14 & 25 & 1.51 & 1.56 & & & 1.28 & 0.18 \\
\hline ZK5-1 & 494 & S. mudstone & 0.09 & 1.09 & 476 & 7.63 & 49 & 2.10 & 2.22 & 1.29 & 0.13 & & 0.18 \\
\hline ZK5-1 & 505 & S. mudstone & 0.08 & 1.43 & 478 & 5.30 & 36 & 3.79 & 3.93 & 1.37 & 0.05 & & 0.33 \\
\hline ZK5-2 & 62 & Mudstone & 0.06 & 1.25 & 468 & 4.58 & 60 & 1.96 & 2.09 & 1.07 & 0.11 & & 0.27 \\
\hline ZK5-2 & 112 & Mudstone & 0.15 & 3.67 & 472 & 3.93 & 82 & 4.10 & 4.47 & 1.09 & 0.09 & & 0.53 \\
\hline ZK5-2 & 175 & Mudstone & 0.03 & 0.56 & 469 & 5.08 & 50 & 1.07 & 1.13 & & & 1.08 & 0.38 \\
\hline ZK2-1 & 50 & Mudstone & 0.02 & 0.15 & 457 & 11.76 & 50 & 0.27 & 0.30 & 0.74 & 0.01 & & 0.07 \\
\hline ZK2-1 & 530 & Mudstone & 0.07 & 0.66 & 468 & 9.59 & 51 & 1.23 & 1.30 & & & 1.05 & 0.20 \\
\hline ZK2-1 & 550 & Mudstone & 0.10 & 0.44 & 470 & 18.52 & 40 & 1.03 & 1.09 & 1.09 & 0.08 & & 0.31 \\
\hline ZK2-2 & 228 & Mudstone & 0.09 & 1.03 & 474 & 8.04 & 56 & 1.72 & 1.85 & & & 1.19 & 0.50 \\
\hline ZK2-2 & 735 & Mudstone & 0.08 & 0.77 & 480 & 9.41 & 36 & 2.07 & 2.15 & & & 1.33 & 0.24 \\
\hline
\end{tabular}

S. mudstone: silty mudstone; EOM: extractable organic matter; $\delta$ n: standard deviation of measured $R_{\mathrm{o}} ; R_{\mathrm{c}-t \text { max }}:$ calculated $R_{\mathrm{o}}$ from $T_{\max }$.

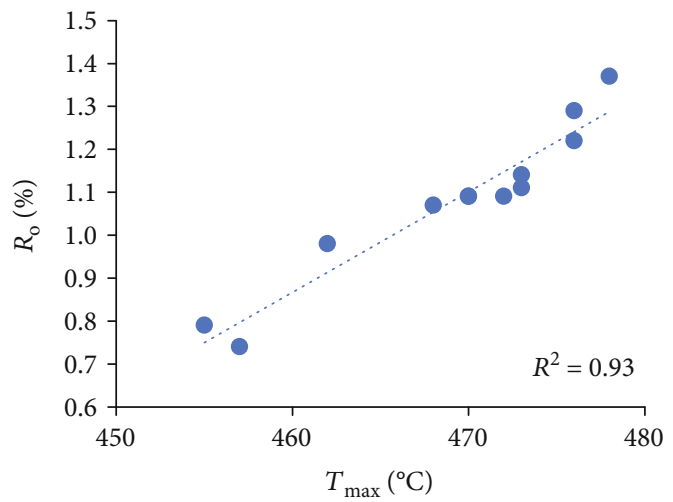

(a)

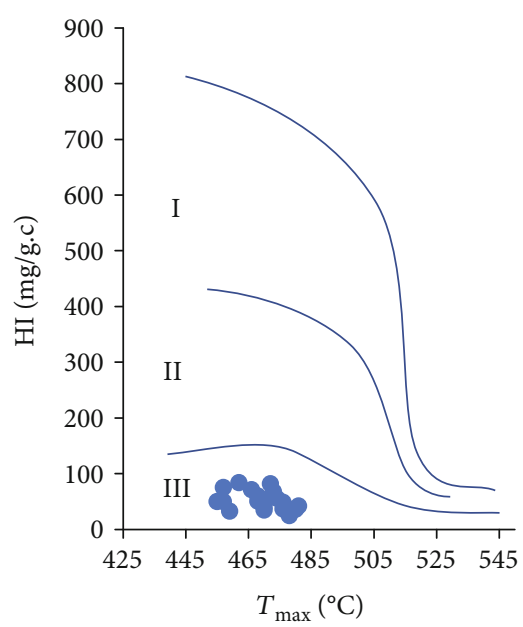

(b)

FIgURe 2: Plot of $T_{\max }$ versus vitrinite reflectance and hydrogen index (HI).

values in the studied samples do not vary systematically with $\% R_{0}, T_{\max }$, and/or depth and cannot serve as maturity proxy (Figure 6(a)). It is generally believed that alkylphenanthrenes found in source rocks and crude oils come from steroids and triterpenoids $[47,48]$ and are related to the abietic and pimaric acid in pine resin $[49,50]$. The 1 - and 2 -MP are mainly derived from type III kerogens, while 9-MP is dominated in type I and II kerogens [51, 52]. With increasing thermal maturity, 9- and 1-MP will be converted to 3- and 2-MP [16]. Phenanthrene was adapted in MPI-1 and MPI-2 ratios to compensate for the influence of different organofacies [14]. The present studied samples are formed under marine to continental transitional deposition system and dominated by type III kerogen. While the subtle variation of organic inputs is inevitable, a very good correlation between methylphenanthrene isomer ratios (MPI-3 and MPR) and burial 


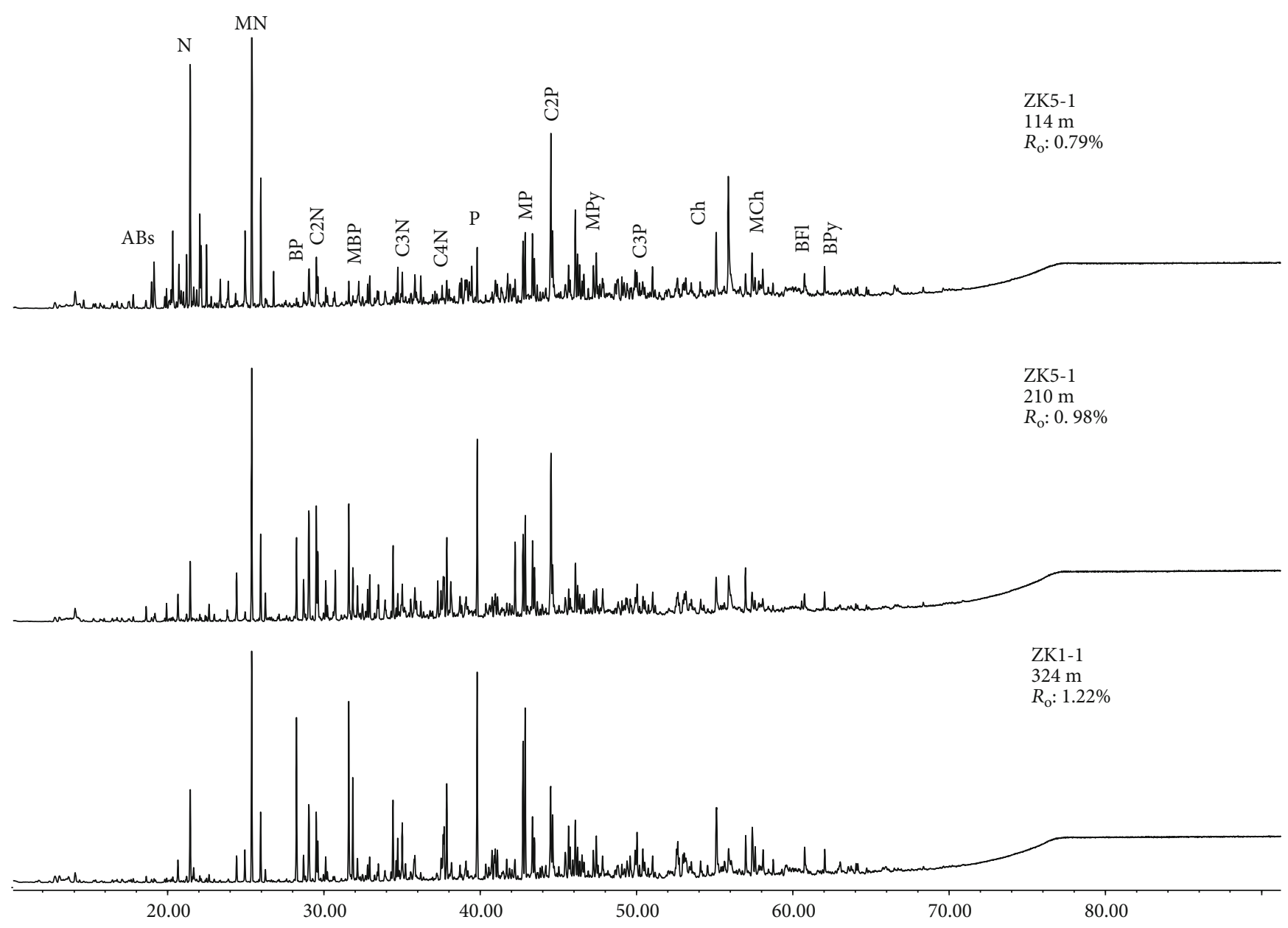

FIgURE 3: Representative total ion chromatograms of the aromatic hydrocarbon fraction in core extracts from the Keluke Formation.

$\operatorname{depth} / R_{\mathrm{o}}$ is consistent with maturity governing thermal stability difference between of 3-, 2-MP and 9-, 1-MP. Therefore, the involvement of phenanthrene makes MPI-1 invalid for maturity correlation [53].

The maturity has an impact on alkylation of the aromatic molecules. Garrigues et al. (1990) found sensible changes on MP and DMP when the samples were heated at $270-500^{\circ} \mathrm{C}$, and alkylated phenanthrene compounds decrease at high temperature over $450^{\circ} \mathrm{C}$. Chakhmakhchev et al. (1997) found relative concentrations of methyl-, dimethyl-, and trimethyldibenzothiophenes are sensitive to maturity. Although the reason for the occurrence of alkylated aromatic compounds is still not clear, Radke [16] proposed that the demethylation of alkylphenanthrenes occurs at $R_{\mathrm{o}}$ of $1.35 \%$, which leads to the decrease of the MPI values at higher maturity level, while Boreham [30] suggested the value of MPI-1 reversal due to the demethylation at $R_{\mathrm{o}}$ of $1.7 \%$. Radke et al. [16] took phenanthrene into maturity parameter calculation to reduce the impact of different facies, while Kvalheim et al. [54] supposed the phenanthrene acts mainly as a scale factor to scale down the relative abundances of methylphenanthrene isomers. However, due to different depositional environments and organic matter types, the alkylation process may be variable in different case histories. Our quantitative data illustrated that the concentrations of 3- and 2-MP increased 380 and $500 \mathrm{ppm}$ at every $0.1 R_{\mathrm{o}}$ incremental interval from 0.74 to $1.37 \%$, while the increment of 9- and 1-MP is only 200 and $150 \mathrm{ppm}$. Meanwhile, the growth of phenanthrene is $773 \mathrm{ppm}$ in the same maturity variation step (Figure 5). The increment of phenanthrene concentration compensates for the difference between $\beta$-type and $\alpha$-type substituent of methylphenanthrenes, resulting in invalid MPI-1 proxy. Much faster increasing phenanthrene concentration than all methylphenanthrene isomers suggest that demethylation occurs much earlier than $R_{\mathrm{o}}$ of $1.35 \%$ or $1.7 \%$. While phenanthrene may have some specific precursors, partial demethylation from methylphenanthrenes cannot be ruled out at least from $R_{\mathrm{o}} 0.74 \%$ in the present study. The extent of phenanthrene alkylation and alkylphenanthrene dealkylation may vary from different types of kerogens or different depositional systems; $R_{\mathrm{o}}$ of $1.35 \%$ or $1.7 \%$ may be suitable for certain kerogen in some geological settings, but unlikely be universally applicable.

The methylphenanthrene isomerization is a steric straindriven rearrangement with a transformation of $\alpha$-type substituent to $\beta$-type substituent $[16,20]$. Early observation of Radke [20] showed that increasing concentrations of 3- and 2-MP were accompanied by parallel decreasing amounts of 


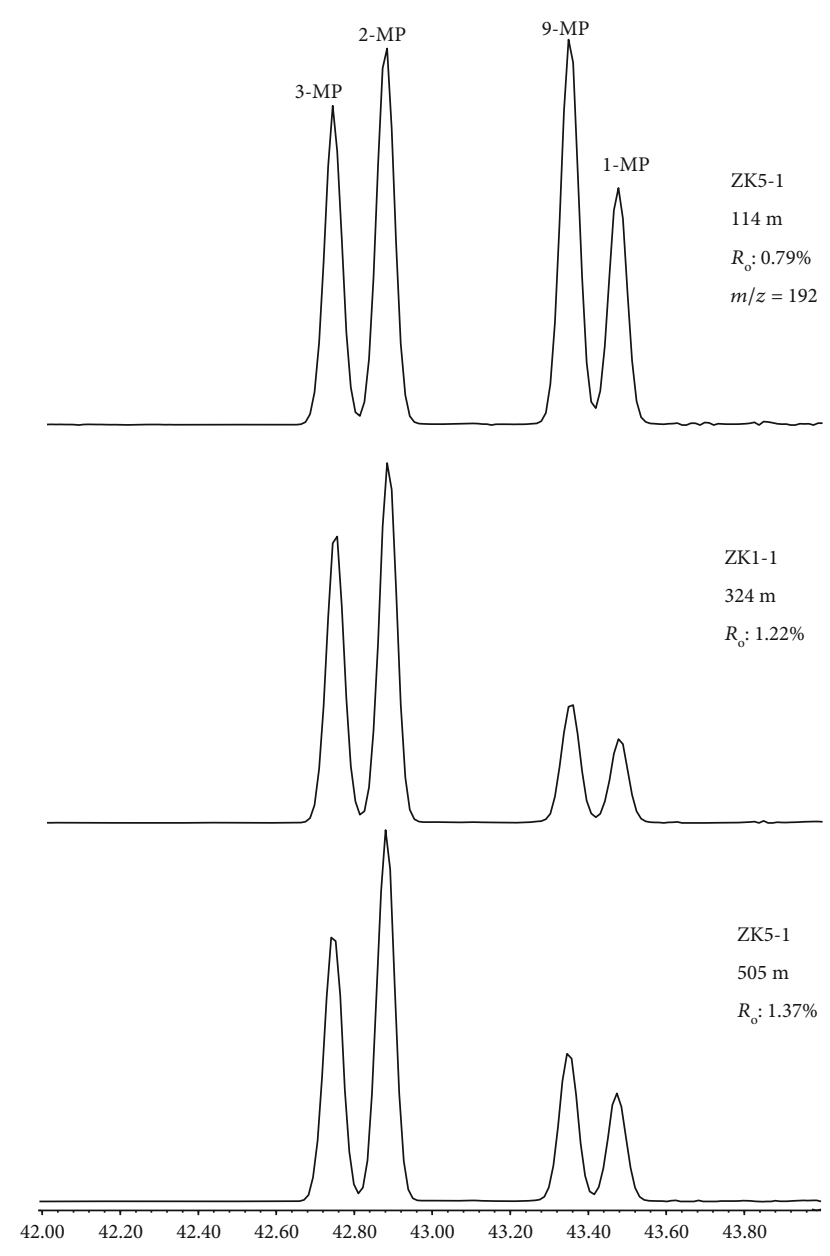

(a)

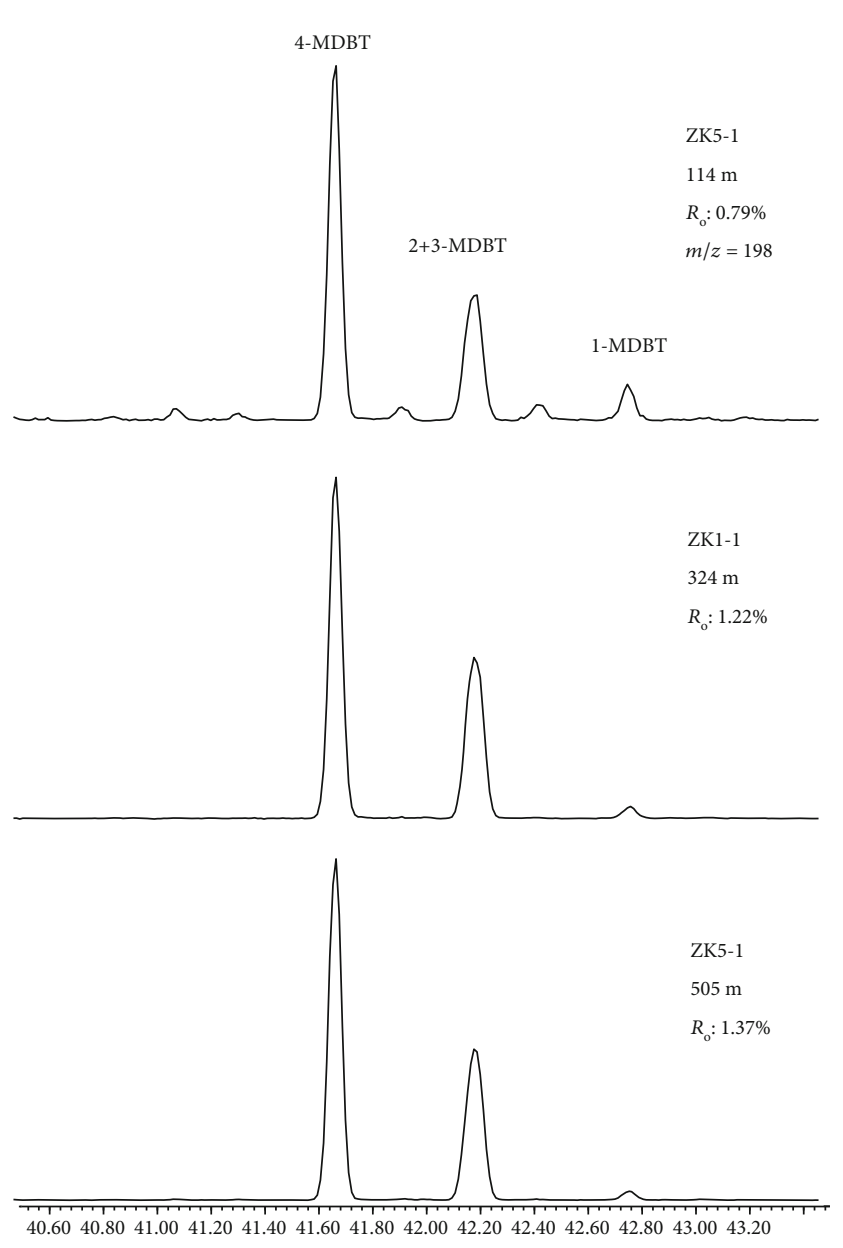

(b)

Figure 4: Partial reconstructed mass chromatograms of $\mathrm{m} / \mathrm{z} 192$ and 198 showing the distributions of methylphenanthrenes and methyldibenzothiophenes in representative core extracts from the Keluke Formation.

9- and 1-MP, suggesting an isomerization process. In our studied samples, the organic inputs are similar and the distribution of methylphenanthrene isomers is strictly controlled by thermal stability. However, as the concentrations of both $\beta$-type and $\alpha$-type substituted methylphenanthrenes increase with increasing maturity at different rates, isomerization from thermally unstable isomers towards more stable isomers can hardly be confirmed.

Similarly, the concentration of 4- and 1-MDBT in the studied samples increases from 18 and 4 ppm to 628 and $24 \mathrm{ppm}$, and 4-MDBT grows much faster than 1-MDBT (Figures 8(a) and 8(b)), especially at high maturity level. The concentrations of 4-MDBT exhibit no linear correlation with increasing maturity. When $R_{\mathrm{o}}$ is $<1.1 \%$, the concentrations of 4 -MDBT increase at a rate about $60 \mathrm{ppm}$ per $0.1 \%$ $R_{\mathrm{o}}$, whereas when $R_{\mathrm{o}}$ is $>1.1 \%$, the 4-MDBT increases 160 ppm per $0.1 \% R_{0}$. However, the changes in the concentrations of 1-MDBT in wide maturity range is insignificant. Our quantitative data show that while both 4- and 1MDBT increase in their concentrations with increasing maturity levels, the increment of 1-MDBT is much slower. The isomerization between 1- and 4-MDBT and methylation or demethylation may happen at the same time, but none of these reactions can be confirmed based on our studies. Dzou [33] suggested the destruction of the less stable isomer rather than any interconversion of isomers based on their experimental results. Our data preferred different generation rates in alkylphenanthrene and alkyldibenzothiophene species to isomerization between isomers with different stabilities, coupled with the demethylation of methylphenanthrenes at peak oil and condensate generation maturity stage, resulting in variable isomer distribution patterns.

5.2. Vitrinite Reflectance Estimations. Calculated vitrinite reflectance can be gained through many maturity parameters, which is particularly useful for source rocks without vitrinite reflectance measurement or oils. Both MDR and MPR were applied for vitrinite reflectance calculations. Since different organic inputs may interfere with MDR variation during maturation, Radke et al. [17] proposed different $R_{\mathrm{c}}$ equations for different kerogen types. A regression for type I and II kerogens was expressed as $R_{\mathrm{c}}=0.40+0.30 \times$ $\mathrm{MDR}-0.094 \times \mathrm{MDR}^{2}+0.011 \times \mathrm{MDR}^{3}$, and the equation for type III kerogens was $R_{\mathrm{c}}=0.51+0.073 \times \mathrm{MDR}$. As our 


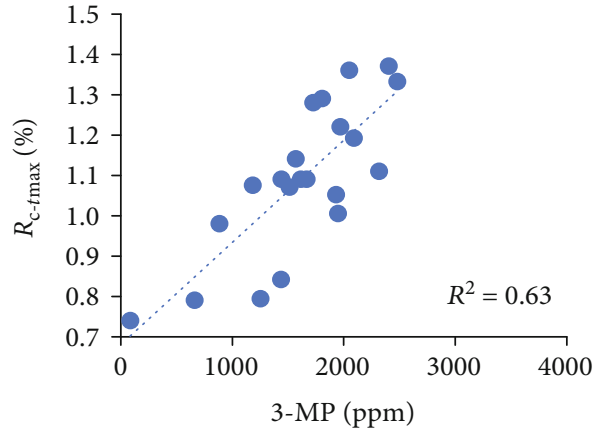

(a)

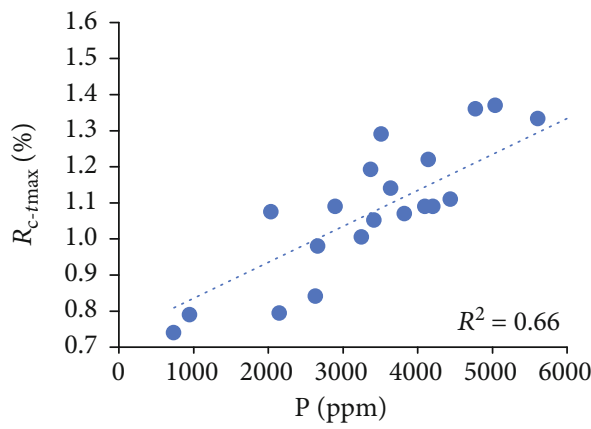

(c)

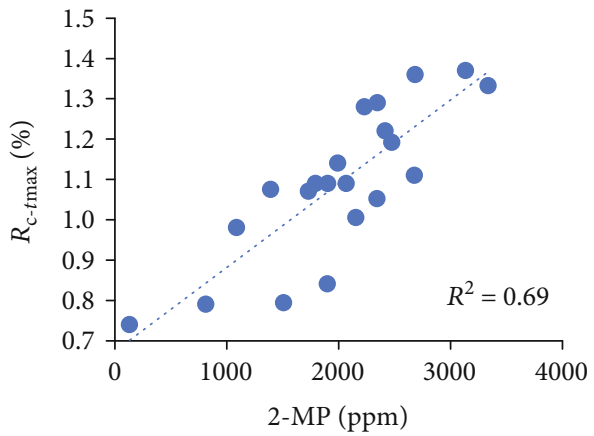

(b)

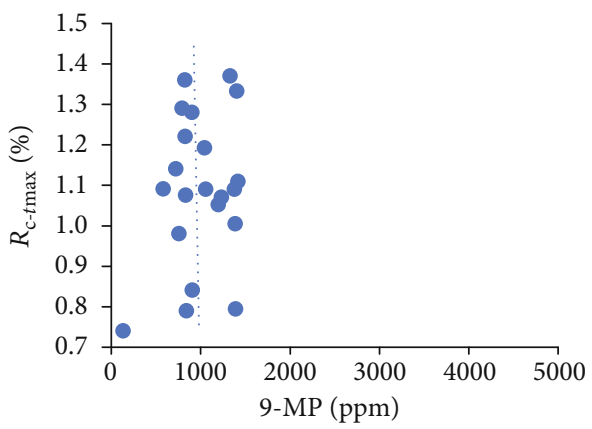

(d)

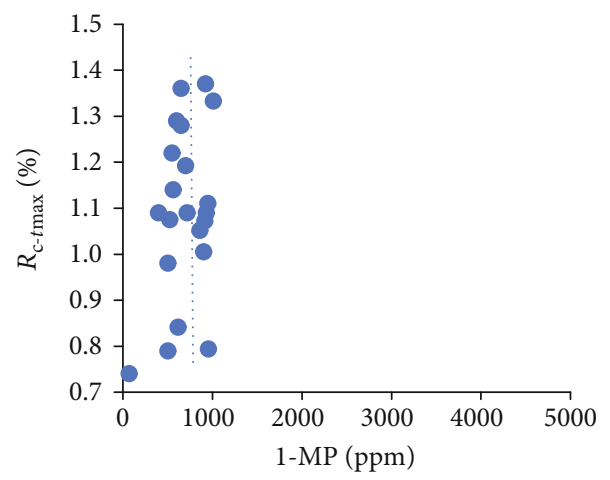

(e)

FIGURE 5: Correlations between concentrations of alkylphenanthrenes and vitrinite reflectance in core extracts from the Keluke Formation. (a) 3-MP, (b) 2-MP, (c) P, (d) 9-MP, and (e) 1-MP.

studied samples are type III kerogens, the equation-derived $R_{\mathrm{c}}$ values are in the range of $0.87-4.03 \%$, which shows a linear relationship with the burial depth. The vitrinite reflectance calculated by MPR can be obtained through the formula of $R_{\mathrm{c}}=0.95+1.1 \times \log _{10}$ MPR [55], and the calculated $R_{\mathrm{c}}$ values in the studied samples are $1.17-1.67 \%$. Figure 9 shows the depth profiles of measurement vitrinite reflectance and those derived from MDR and MPR estimations.

While the vitrinite reflectance values calculated from MPR are 1.3 to 1.4 times higher than those measured ones, differences between MDR derived $R_{\mathrm{c}}$ and measured $R_{\mathrm{o}}$ are abnormally high and the gap increases with increasing maturity values. Although the vitrinite reflectance calculated by MDR has linear regression with burial depth as depth= $192.13 \times R_{\mathrm{c}-\mathrm{MDR}}-133.17$, the value can only describe the tendency of maturity and cannot be regarded as vitrinite reflectance equivalency in our samples. Our data further emphasizes that the thermal stability of methylphenanthrene and methyldibenzothiophene isomers do control their relative abundance during thermal evolution, but the ratio values have very different responses in different source rock systems. In addition to kerogen types, depositional facies, redox conditions, mineralogy of sedimentary rocks, and even the ages of source rocks may all exert some impacts on methylphenanthrene and methyldibenzothiophene isomer distribution patterns. The vitrinite reflectance calculations are mainly applicable for the calibrated source rocks and oils derived from these source rocks. While ratio values of methylphenanthrene and methyldibenzothiophene isomers are maturity related, the different lithology, depositional environment, and organic inputs should be taken into consideration. Mechanically using these empirical formulas may derive the 


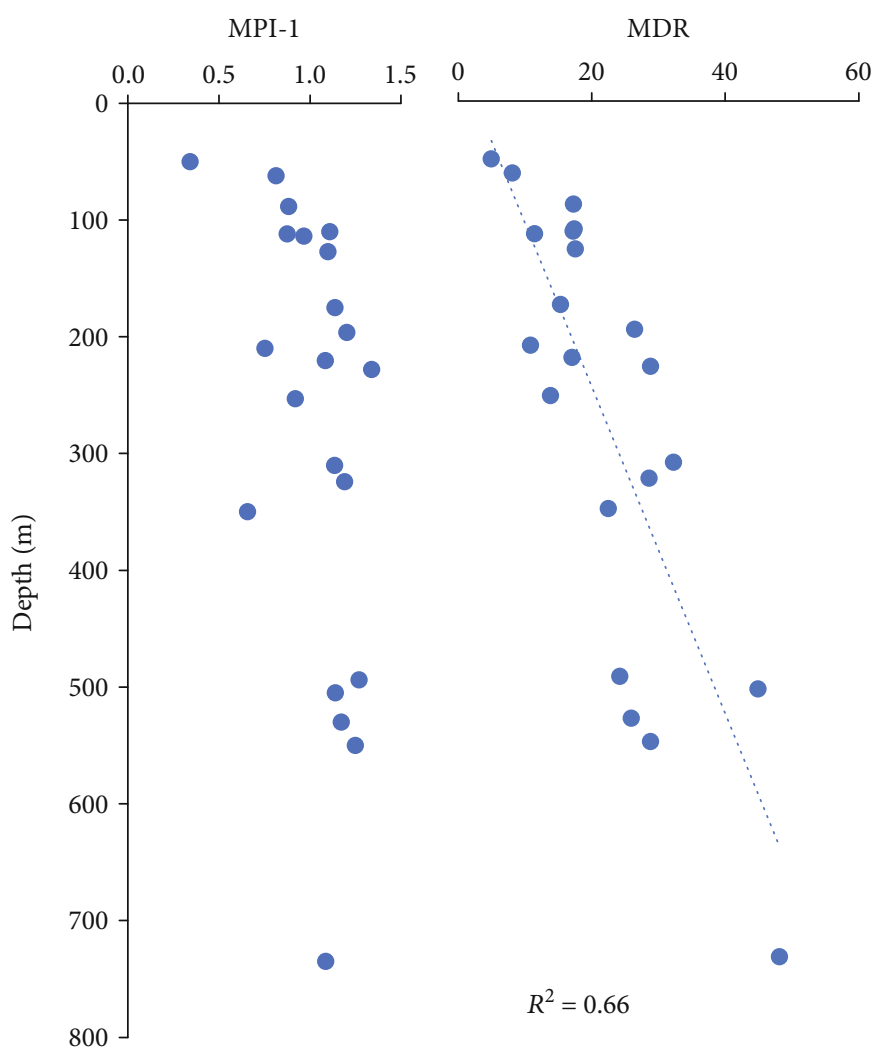

(a)

(b)

FIGURE 6: Depth profiles of MPI-1 and MDR in core extracts from the Keluke Formation.

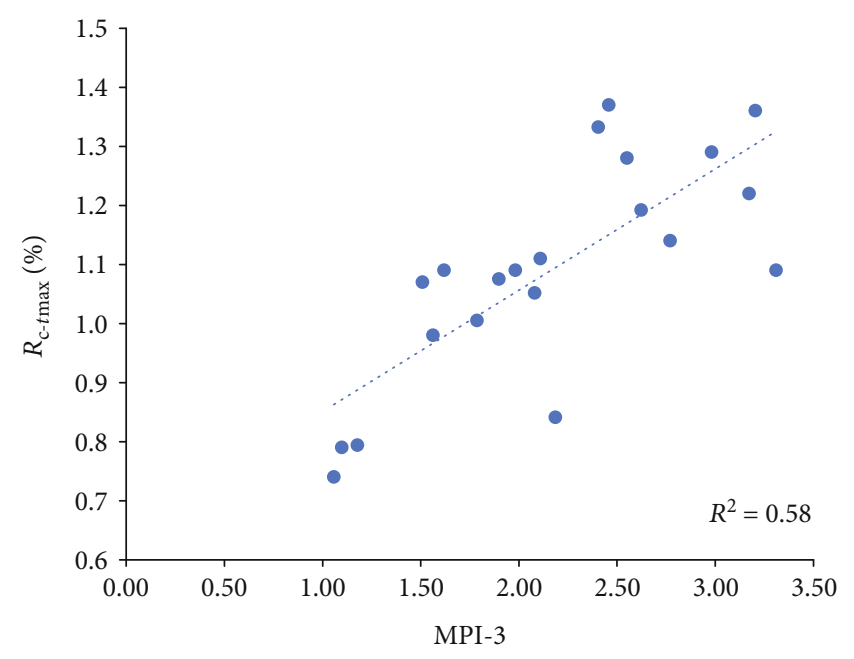

FIGURE 7: Correlation between MPI-3 and measured vitrinite reflectance in core extracts from the Keluke Formation.

misleading maturity estimation, and caution should be taken for such application.

\section{Conclusion}

The Carboniferous Keluke Formation in the Qaidam basin, NW China, was formed in marine to continental transitional facies and dominated by type III kerogen. The source rocks are highly matured with Rock-Eval $T_{\max }$ values of 455$481^{\circ} \mathrm{C}$ and vitrinite reflectance $\left(R_{\mathrm{o}}\right)$ values of $0.74-1.37 \%$. The remaining hydrocarbon generation potential is quite low as evidenced by the dominance of residual carbon, low hydrogen index, and extractable organic matter yield. The methylphenanthrene (MP) and methyldibenzothiophene (MDBT) isomer distributions show systematic variation with maturity levels. The relative abundance of thermally stable isomers of 3-MP, 2-MP, and 4-MDBT increases against thermally unstable isomers of 9-MP, 1-MP, and 1-MDBT, and ratios of MPI-3, MPR, and MDR are linearly correlated to known maturity levels. However, the MPI-1 values show no correlation with maturity due to the involvement of phenanthrene in maturity estimation formula. A faster increment in the concentration of phenanthrene compensates the difference between different thermal stability of methylphenanthrene isomers. Demethylation of methylphenanthrenes to form phenanthrene may occur much earlier than literature reported of $R_{\mathrm{o}} 1.35 \%$. Meanwhile, isomerization between thermally unstable and stable isomers can hardly be confirmed as different generation rates control isomer ratio values in our studied samples. Vitrinite reflectance values calculated from empirical formulas based on MDR and MPR ratios have no merit for maturity assessment. No universal correlation should be expected from isomer ratios as they are governed by complicated geological and geochemical processes in addition to thermal stability differences. 


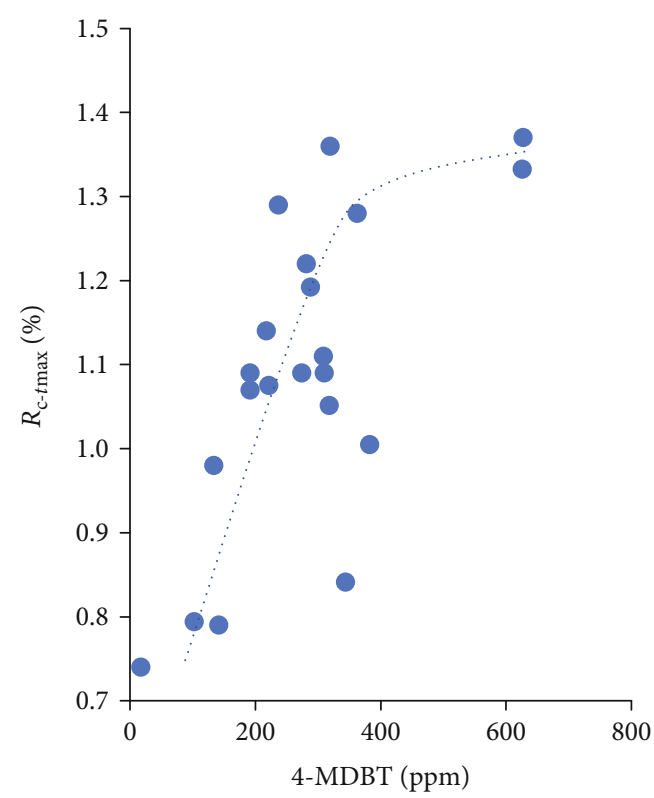

(a)

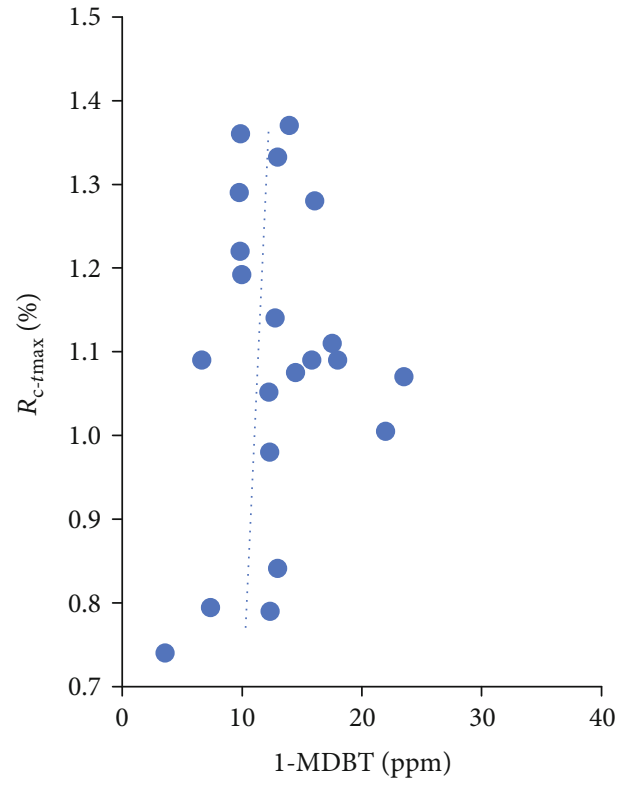

(b)

FIGURE 8: Correlations between concentrations of alkyldibenzothiophenes and measured vitrinite reflectance in core extracts from the Keluke Formation. (a) 4-MDBT; (b) 1-MDBT.

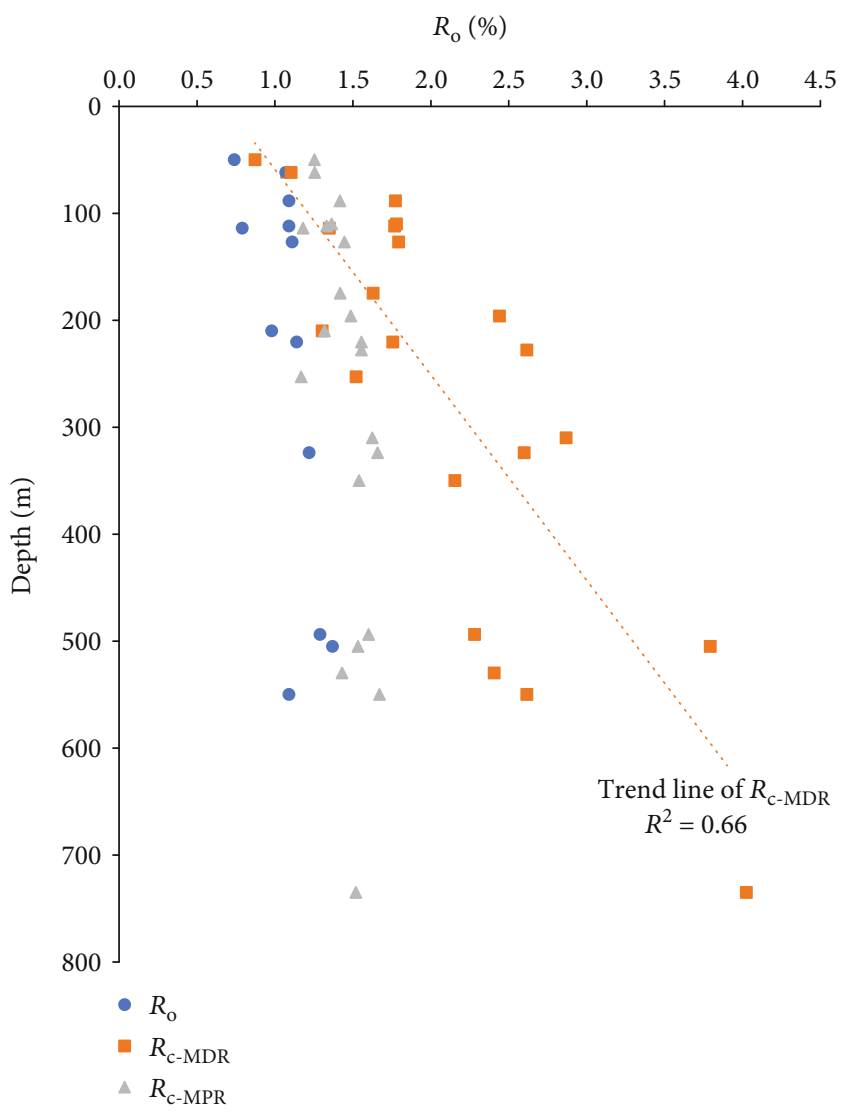

FIGURE 9: Depth profiles of measured vitrinite reflectance and calculated vitrinite reflectance values from empirical correlations based on MPR and MDR in core extracts from the Keluke Formation.

\section{Data Availability}

The data used to support the findings of this study are available from the corresponding author upon request.

\section{Conflicts of Interest}

The authors declare that they have no conflicts of interest.

\section{Acknowledgments}

This work was supported by the National Natural Science Foundation of China (Grant Numbers 41573035, 41772272, and 41873049). The PRG research team provided valuable experimental support for this research program. Bo Peng, Dapeng Liu, and Jiaqi Wang from the Institute of Geomechanics CAGS are gratefully acknowledged for the fieldwork. We would like to thank Paul C. Hackley for the thoughtful comments and efforts towards improving our manuscript.

\section{References}

[1] H. Huang and M. J. Pearson, "Source rock palaeoenvironments and controls on the distribution of dibenzothiophenes in lacustrine crude oils, Bohai Bay Basin, eastern China," Organic Geochemistry, vol. 30, no. 11, pp. 1455-1470, 1999.

[2] J. M. Moldowan, W. K. Seifert, and E. J. Gallegos, "Relationship between petroleum composition and depositional environment of petroleum source rocks," AAPG Bulletin, vol. 69, no. 8, pp. 1255-1268, 1985.

[3] K. E. Peters, J. M. Moldowan, M. Schoell, and W. B. Hempkins, "Petroleum isotopic and biomarker composition related to source rock organic matter and depositional environment," Organic Geochemistry, vol. 10, no. 1-3, pp. 17-27, 1986. 
[4] M. Radke, "Application of aromatic compounds as maturity indicators in source rocks and crude oils," Marine and Petroleum Geology, vol. 5, no. 3, pp. 224-236, 1988.

[5] L. R. Snowdon and T. G. Powell, "Immature oil and condensate--modification of hydrocarbon generation model for terrestrial organic matter," AAPG Bulletin, vol. 66, no. 6, pp. 775-788, 1982.

[6] A. S. Mackenzie and J. R. Maxwell, "Assessment of thermal maturation in sedimentary rocks by molecular measurements," in In Organic maturation studies and fossil fuel exploration, pp. 239-254, Academic Press London, 1981.

[7] P. Farrimond, A. Taylor, and N. TelnÆs, "Biomarker maturity parameters: the role of generation and thermal degradation," Organic Geochemistry, vol. 29, no. 5-7, pp. 1181-1197, 1998.

[8] G. W. Van Graas, "Biomarker maturity parameters for high maturities: Calibration of the working range up to the oil/condensate threshold," Organic Geochemistry, vol. 16, no. 4-6, pp. 1025-1032, 1990.

[9] A. Wilhelms and S. Larter, Shaken but not always stirred. Impact of petroleum charge mixing on reservoir geochemistry, vol. 237, Special Publications, Geological Society, London, 2004.

[10] B. P. Tissot and D. H. Welte, Petroleum Formation and Occurrence, Springer-Verlag, New York, 1984.

[11] R. Alexander, R. I. Kagi, S. J. Rowland, P. N. Sheppard, and T. V. Chirila, "The effects of thermal maturity on distributions of dimethylnaphthalenes and trimethylnaphthalenes in some ancient sediments and petroleums," Geochimica et Cosmochimica Acta, vol. 49, no. 2, pp. 385-395, 1985.

[12] R. Alexander, K. M. Cumbers, and R. I. Kagi, "Alkylbiphenyls in ancient sediments and petroleums," Organic Geochemistry, vol. 10, no. 4-6, pp. 841-845, 1986.

[13] R. Alexander, M. G. Strachan, R. I. Kagi, and W. Van Bronswijk, "Heating rate effects on aromatic maturity indicators," Organic Geochemistry, vol. 10, no. 4-6, pp. 997-1003, 1986.

[14] M. Radke and D. H. Welte, "The methylphenanthrene index (MPI): a maturity parameter based on aromatic hydrocarbons, advances in organic geochemistry," Advances Organic Geochemistry, vol. 1981, pp. 504-512, 1983.

[15] M. Radke, "Organic geochemistry of aromatic hydrocarbons," Advances in Petroleum Geochemistry, vol. 2, pp. 141-207, 1987.

[16] M. Radke, D. H. Welte, and H. Willsch, "Geochemical study on a well in the Western Canada Basin: relation of the aromatic distribution pattern to maturity of organic matter," Geochimica et Cosmochimica Acta, vol. 46, no. 1, pp. 1-10, 1982.

[17] M. Radke, D. H. Welte, and H. Willsch, "Maturity parameters based on aromatic hydrocarbons: influence of the organic matter type," Organic Geochemistry, vol. 10, no. 1-3, pp. 51-63, 1986.

[18] A. G. Requejo, R. Sassen, T. McDonald, G. Denoux, M. C. Kennicutt Ii, and J. M. Brooks, "Polynuclear aromatic hydrocarbons (PAH) as indicators of the source and maturity of marine crude oils," Organic Geochemistry, vol. 24, no. 10-11, pp. 1017-1033, 1996.

[19] H. Willsch and M. Radke, "Distribution of polycyclic aromatic compounds in coals of high rank," Polycyclic Aromatic Compounds, vol. 7, no. 4, pp. 231-251, 1995.

[20] M. Radke, H. Willsch, D. Leythaeuser, and M. Teichmüller, "Aromatic components of coal: relation of distribution pattern to rank," Geochimica et Cosmochimica Acta, vol. 46, no. 10, pp. 1831-1848, 1982.

[21] A. Chakhmakhchev and N. Suzuki, "Aromatic sulfur compounds as maturity indicators for petroleums from the Buzuluk depression, Russia," Organic Geochemistry, vol. 23, no. 7, pp. 617-625, 1995.

[22] A. Bechtel, R. Gratzer, W. Püttmann, and S. Oszczepalski, "Geochemical and isotopic composition of organic matter in the Kupferschiefer of the Polish Zechstein basin: relation to maturity and base metal mineralization," International Journal of Earth Sciences, vol. 89, no. 1, pp. 72-89, 2000.

[23] S. C. George, T. E. Ruble, A. Dutkiewicz, and P. J. Eadington, "Assessing the maturity of oil trapped in fluid inclusions using molecular geochemistry data and visually-determined fluorescence colours," Applied Geochemistry, vol. 16, no. 4, pp. 451473, 2001.

[24] H. Huang, S. Zhang, and J. Su, "Geochemistry of tri-and tetracyclic terpanes in the palaeozoic oils from the Tarim basin, Northwest China," Energy \& Fuels, vol. 29, no. 11, pp. 70147025, 2015.

[25] M. Li, T. . G. Wang, S. Shi, L. Zhu, and R. Fang, "Oil maturity assessment using maturity indicators based on methylated dibenzothiophenes," Petroleum Science, vol. 11, no. 2, pp. 234-246, 2014.

[26] M. Radke, J. Rullkötter, and S. P. Vriend, "Distribution of naphthalenes in crude oils from the Java Sea: source and maturation effects," Geochimica et Cosmochimica Acta, vol. 58, no. 17, pp. 3675-3689, 1994.

[27] S. Zhang, H. Huang, J. Su, G. Zhu, X. Wang, and S. Larter, "Geochemistry of Paleozoic marine oils from the Tarim Basin, NW China. Part 4: paleobiodegradation and oil charge mixing," Organic Geochemistry, vol. 67, pp. 41-57, 2014.

[28] F. Cassani, O. Gallango, S. Talukdar, C. Vallejos, and U. Ehrmann, "Methylphenanthrene maturity index of marine source rock extracts and crude oils from the Maracaibo Basin," Organic Geochemistry, vol. 13, no. 1-3, pp. 73-80, 1988.

[29] W. Püttmann, M. Wolf, and E. Wolff-Fischer, "Chemical characteristics of liptinite macerals in humic and sapropelic coals," Organic Geochemistry, vol. 10, no. 1-3, pp. 625-632, 1986.

[30] C. J. Boreham, I. H. Crick, and T. G. Powell, "Alternative calibration of the methylphenanthrene index against vitrinite reflectance: application to maturity measurements on oils and sediments," Organic Geochemistry, vol. 12, no. 3, pp. 289-294, 1988.

[31] K. Chandra, C. S. Mishra, U. Samanta, A. Gupta, and K. L. Mehrotra, "Correlation of different maturity parameters in the Ahmedabad-Mehsana block of the Cambay basin," Organic Geochemistry, vol. 21, no. 3-4, pp. 313-321, 1994.

[32] C. M. Norgate, C. J. Boreham, and A. J. Wilkins, "Changes in hydrocarbon maturity indices with coal rank and type, Buller Coalfield, New Zealand," Organic Geochemistry, vol. 30, no. 8, pp. 985-1010, 1999.

[33] L. I. P. Dzou, R. A. Noble, and J. T. Senftle, "Maturation effects on absolute biomarker concentration in a suite of coals and associated vitrinite concentrates," Organic Geochemistry, vol. 23, no. 7, pp. 681-697, 1995.

[34] Z. Li, N. Qiu, Y. Ma, Y. Guo, and Y. Xiao, "The study on tectono-thermal evolution since Paleozoic in the eastern Qaidam Basin, northwest China," Earth Science Frontiers, vol. 24, no. 3, pp. 157-167, 2017. 
[35] Z. Wen, Z. Wang, Y. He, and D. Peng, "Evaluation on Upper Carboniferous hydrocarbon source rock in the northern margin of Chaidamu Basin," Natural Gas Geoscience, vol. 15, no. 2, pp. 125-127, 2004.

[36] S. Chen, J. Liu, S. Ma, C. Liu, and Z. Li, "Characteristics of Keluke shale reservoirs in northeast margin of Qaidam Basin," Earth Science Frontiers, vol. 23, no. 5, pp. 55-56, 2016.

[37] C. Liu, Y. Ma, G. Zhou, C. Yin, and J. Du, "Evidence for the Carboniferous hydrocarbon generation in Qaidam Basin," Acta Petrolei Sinica, vol. 33, no. 5, pp. 925-931, 2012.

[38] Y. Ma, C. Yin, C. Liu, J. Du, and H. Cheng, "The progress of Carboniferous oil and gas investigation and assessment in Qaidam Basin," Acta Geoscientica Sinica, vol. 33, no. 2, pp. 135144, 2012.

[39] J. Cao, C. Liu, Y. Ma et al., "Geochemical characteristics and genesis of shale gas for Carboniferous marine-continental transitional facies coal measure strata in Eastern Qaidam Basin," Earth Science Frontiers, vol. 23, no. 5, pp. 158-166, 2016.

[40] N. Su, Z. Jin, F. Song, J. Gu, Y. Chen, and W. Zhang, "Sedimentary characteristics and evolution of Neogene in Qaidam Basin," Journal of Central South University (Science and Technology), vol. 46, no. 11, pp. 4155-4164, 2015.

[41] A. Yin, Y. Dang, X. Chen et al., "Cenozoic evolution and tectonic reconstruction of the Qaidam Basin: evidence from seismic profiles," Journal of Geomechanics, vol. 13, no. 3, pp. 193-211, 2007.

[42] F. Behar, V. Beaumont, and H. L. de B Penteado, "Rock-Eval 6 technology: performances and developments," Oil \& Gas Science and Technology, vol. 56, no. 2, pp. 111-134, 2001.

[43] T. P. Bastow, B. G. K. van Aarssen, and D. Lang, "Rapid smallscale separation of saturate, aromatic and polar components in petroleum," Organic Geochemistry, vol. 38, no. 8, pp. 12351250, 2007.

[44] D. M. Jarvie, B. L. Claxton, F. Henk, and J. T. Breyer, "Oil and shale gas from the Barnett Shale, Ft," in AAPG Annual Meeting Program, vol. 10, p. A100, Worth Basin, Texas (abs.), 2001.

[45] J. Cao, "Study on enrichment mechanism of organic matter in Carboniferous source rocks in the eastern Qaidam Basin," Postdoctoral Research Report. Chinese Academy of Geological Sciences, pp. 50-53, 2017.

[46] L. Wang, "Carboniferous petroleum resource assessment in the eastern Qaidam Basin," Doctoral Thesis, Chinese Academy of Geological Sciences, 2019.

[47] A. C. Greiner, C. Spyckerelle, and P. Albrecht, "Aromatic hydrocarbons from geological sources-I : New naturally occurring phenanthrene and chrysene derivatives," Tetrahedron, vol. 32, no. 2, pp. 257-260, 1976.

[48] B. J. Mair, "Terpenoids, fatty acids and alcohols as source materials for petroleum hydrocarbons," Geochimica et Cosmochimica Acta, vol. 28, no. 8, pp. 1303-1321, 1964.

[49] R. E. Laflamme and R. A. Hites, "The global distribution of polycyclic aromatic hydrocarbons in recent sediments," Geochimica et Cosmochimica Acta, vol. 42, no. 3, pp. 289-303, 1978.

[50] S. G. Wakeham, C. Schaffner, and W. Giger, "Poly cyclic aromatic hydrocarbons in Recent lake sediments-II. Compounds derived from biogenic precursors during early diagenesis," Geochimica et Cosmochimica Acta, vol. 44, no. 3, pp. 415429, 1980.
[51] H. Heppenheimer, K. Steffens, W. Püttman, and W. Kalkreuth, "Comparison of resinite-related aromatic biomarker distributions in Cretaceous- Tertiary coals from Canada and Germany," Organic Geochemistry, vol. 18, no. 3, pp. 273-287, 1992.

[52] N. P. Tupper and D. M. Burckhardt, "Use of the methylphenanthrene index to characterise expulsion of Cooper and Eromanga Basin oils," The APPEA Journal, vol. 30, no. 1, pp. 373-385, 1990.

[53] Z. Li, H. Huang, C. He, and X. Fang, "Maturation impact on polyaromatic hydrocarbons and organosulfur compounds in the Carboniferous Keluke Formation from Qaidam Basin, NW China," Energy \& Fuels, vol. 33, no. 5, pp. 4115-4129, 2019.

[54] O. M. Kvalheim, A. A. Christy, N. Telnæs, and A. Bjørseth, "Maturity determination of organic matter in coals using the methylphenanthrene distribution," Geochimica et Cosmochimica Acta, vol. 51, no. 7, pp. 1883-1888, 1987.

[55] M. Radke, D. Leythaeuser, and M. Teichmüller, "Relationship between rank and composition of aromatic hydrocarbons for coals of different origins," Organic Geochemistry, vol. 6, pp. 423-430, 1984. 

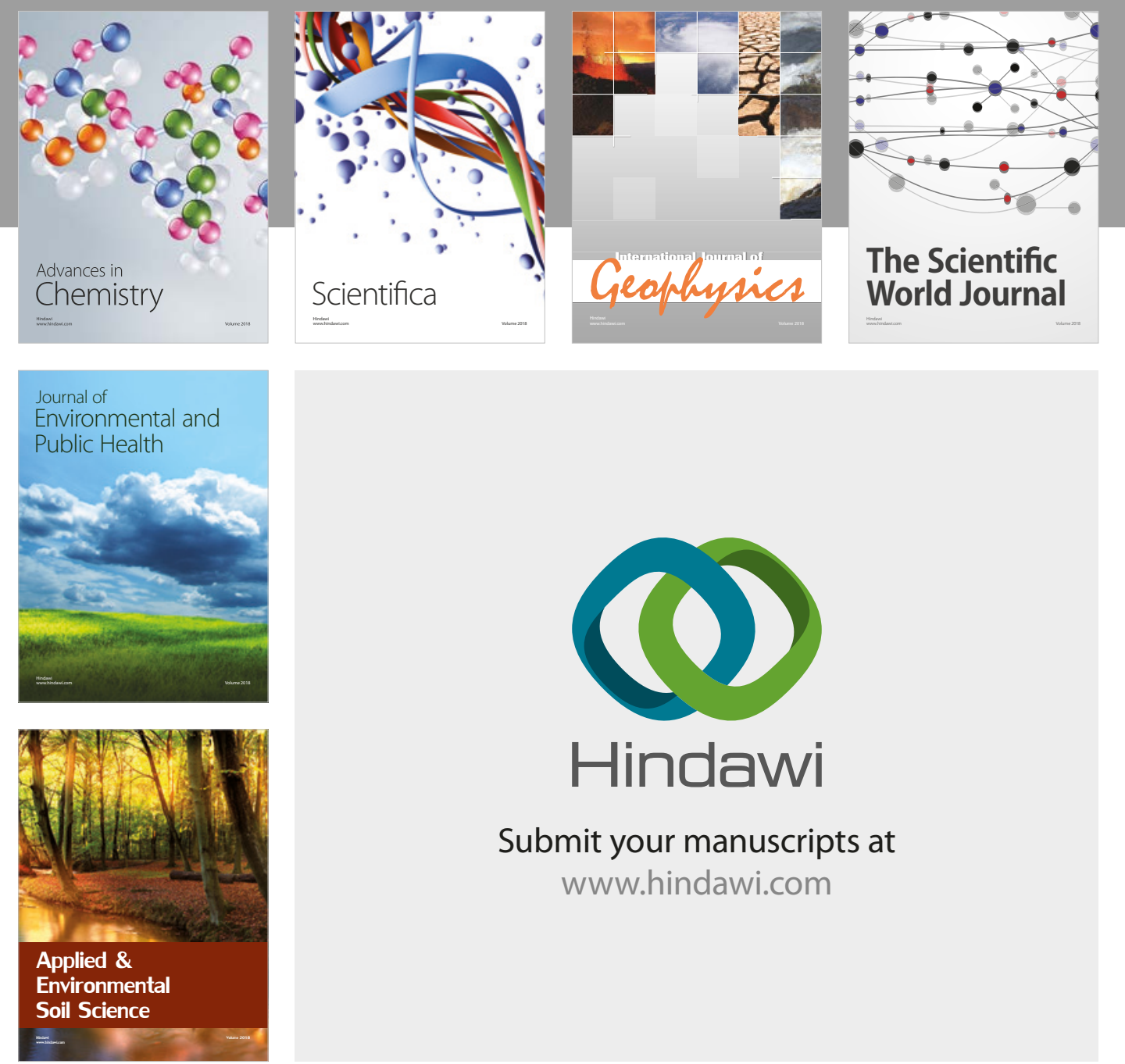

The Scientific

\section{World Journal}
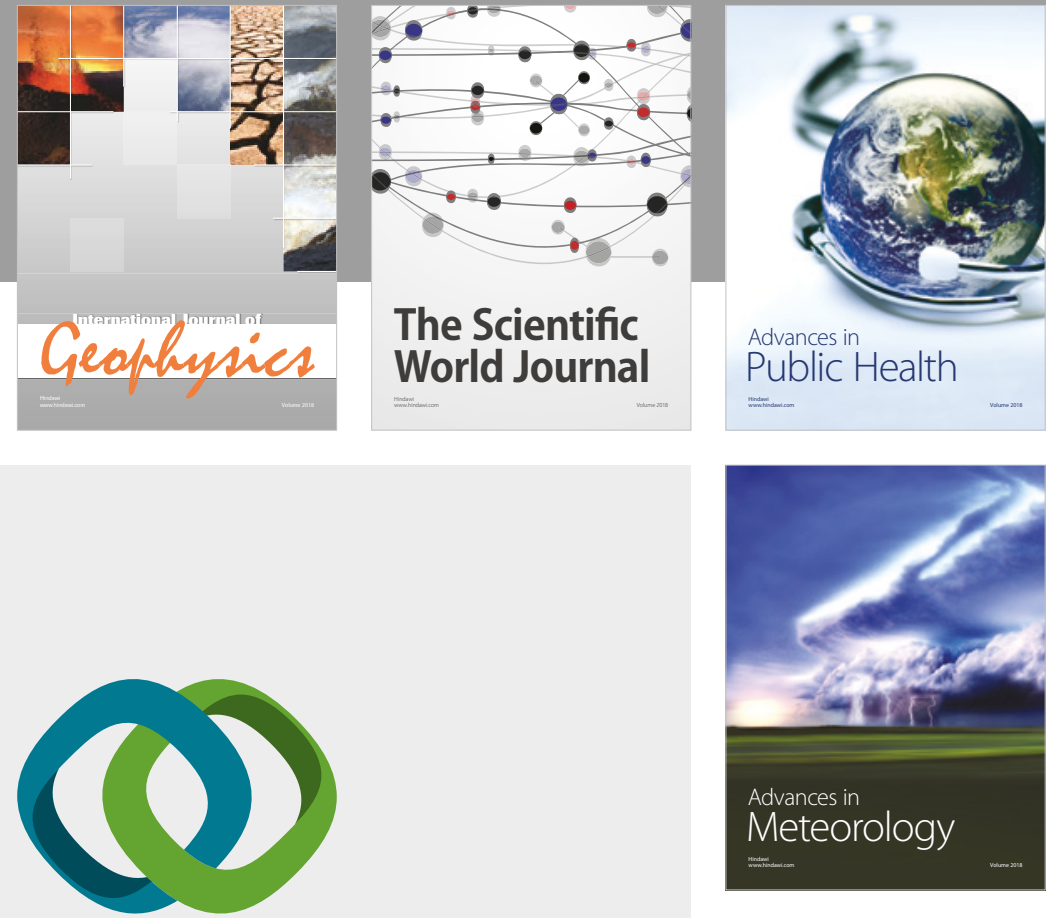

Advan

Public Health

\section{Hindawi}

Submit your manuscripts at

www.hindawi.com
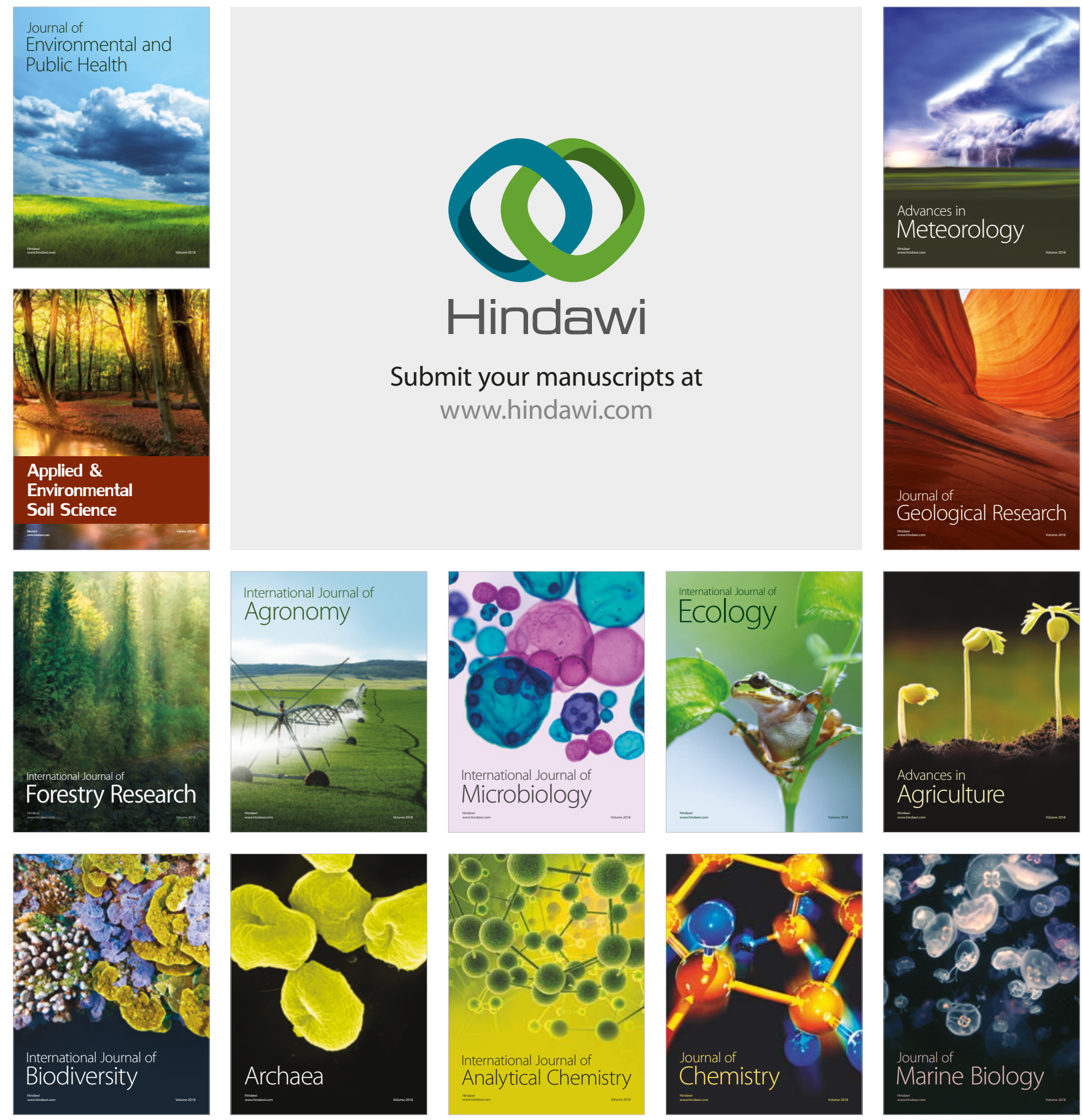